\title{
Information as the fourth vital element and its influence on the culture of peoples*
}

\author{
North Holland \\ Journal of Information Science 13 (1987) 149-157
}

\author{
Emilia Currás \\ Gabinete de Documentación Científica, Universidad Autónoma de Madrid, 28049 Madrid, Spain
}

Received 18 June 1986

Revised 3 February 1987

Almongst the various possible subjects that occurred to me within the fields of experimental science and the humanities, I decided to choose a question of great importance today -that of information and its influence on the historical evolution of the culture of peoples.

Through this subject, I shall be able to explain, in general terms, my thoughts and opinions, which I would like to believe contain philosophical and historical traces.

Inspired by contemporary philosophers, Dr. Martínez Fornes is of the idea that, as Alonso Quijano died unmarried and without issue, we are all children of Sancho Panza -positivistic, realistic, with our the ground, somewhat pessimistic, without a trace of spirituality. I, if you will permit me, prefer to think that I have descended from Don Quijote's niece; and that I have inherited some genes from an idealist, dreamer and, to some extent, and optimist.

With this mixture of Don Quijote and Sancho, I shall now go on to give my talk on the subject "Information as the fourth vital element and its influence on the culture of peoples".

\section{Explanation of the title}

In a telephone conversation a few days ago, I mentioned this subject to Don Javier Lasso de la Vega, that pioneer of all pioneers in documentation sciences, and he replied: "That's not a title. It's a complete definition". I put down the telephone and began to think the matter over and I realized that, once again, he was right.

It is a definition and, as such, it requires an explanation. Its postulate has to be based on certain principles from which the conclusion we propose can be deduced.

Nowadays one is bound to talk of information. We are immersed in its world. A world that is evolving, in which it is necessary to reflect upon so many attributes, characteristics, beneficial agents and contaminating factors. Today, reference is made to a theory of knowledge based on informationism. I first used that term in an article published in the Revista de la Universidad Complutense in 1981 (8). In other words, very recently. It is now accepted as being evident. We are undergoing periods of great evolution. 
Likewise, it is commonly stated that we have left the atomic energy age and are now entering the era of information. In previous articles, I also have accepted these statements. Today, when mediating upon this affirmations, I feel that the atomic energy era has not ended, nor is it likely to for a long time. The information era, however, has existed ever since the world has existed, or at least since life began on the planet Earth. Information has always existed and will continue to do so for centuries to come because it is the "fourth vital element", as we shall now try to demonstrate.

Human beings, be they homo sapiens, homo sociologicus or homo informaticus, tend to relate their existence and thoughts to the parameters of the present moment.

*Introductory speech to the Real Academia de Bellas Artes y Ciencias Históricas de Toledo.

For this reason we speak of the information age as a new and marvellous discovery. It is my belief that we are confusing "information" with "information technology", which has entirely different connotations. A more appropriate expression would be the "information technology age".

We are neither in the atomic age nor in the information technology age, we are in both and perhaps on some other. Our world is not a simple place. It is complex, with a complexity that in information to be "a physical act followed by a psychic act" (29). By physical act, he is referring to a message, impact, external stimulus, whereas the psychic act involves the mental activity of perceiving and assimilating this message.

We may continue by talking of information as each piece that combines to form a whole and enables us to carry out research tasks. This definition proposed by Klintoe in a unplublished lecture provides a component of practical and, at the same time, transcendental utility. For it is though research that we arrive at science, and through science we obtain the truth. Subjective truth is relative, human. Objective truth, is absolute and is beyond our reach.

We can likewise consider information as the first element in the search for wisdom, in a human chain process, that arises from documentation. This documentation produces information, which converts into documentation and once again into information. It is a continuous and theoretically infinite process. In practice it will terminate with the end of human life on Earth.

Information has also been defined as the process by which we receive the events of the external world, giving us the opportunity to form judgements and make decisions: economic, political, moral, scientific, and so on.

We could even say that information is the consequence of documentation. It does not exist in itself, it needs documentation, a set of documents that are suitably prepared so that data, quanta of useful information, can be extracted and transmitted to whoever requires them.

Many more definitions could come to mind, and more and more can be found in the literature. The definitions given here are, for the moment, sufficient for our reflections. 


\section{The nature of information}

The aforementioned definitions can be divided into two main groups that refer to the nature of information when considered as:

-a phenomenon, produced around us, independently of our ego and which we grasp either consciously or unconsciously.

We can also speak of

-a phenomenon, produced by the background of our noosphere which surrounds us and forms the development of our daily activities.

At the same time information is

-a process: prepared by us, from some documents, for its subsequent use.

It can likewise be expressed as:

-a process: as a consequence of documentation, that consciously the activities of the human intellect, affecting the development of Mankind, either scientifically, technically or artistically.

This dual aspect of phenomenon and process provides information with a holistic character, from which it can be concluded that information is "everything"; the essence and presence of any human activity, be it conscious or unconscious. For this reason the Anglophone world use the term "information science" to include all informational concepts.

For there to be information, the following requirements have to be fulfilled:

-it has to be transmitted,

-it has to be perceived.

In others words, there has to be "communication". Hence, we find information and communication linked in such a way that they can be confused and many writers refer indistinctly to one or the other.

One should, however, recall that information on itself has always existed and that the new techniques, the so-called "information technologies" are really techniques for processing, storing, reproducing, transmitting... Going back to my former line of reasoning, it would perhaps be more correct if I stated that we are in the "communication era", in accordance with Bradford Morse (24). Carl Keren evaluates the development of a country by how much it uses information (considered as a process). Professor Kaula. From India, makes reference to the development of communication channels (15).

\section{The impact of information on the development of the human being}

When I speak of the human being, I like to think of him in the centre of an evolutionary process, originating in the macrocosmos and reaching the microcosmos. Man is the element (being, machine) that transforms the macrocosmos and microcosmos so as to use both, by assimilation.

Whatever the truth, the Universe appears to be ruled by logical and exact laws that are inexorably obeyed, without admitting and degree of imprecision. Although we might consider it to be haphazard and unpredictable this is no more than the result of our ignorance. We are still far from knowing the true reality.

For our line of reasoning, we have to think of the Universe as an energy potential. An energy that manifest itself in its most varied aspect, from matter or mass in our human dimension it is a form of concentrated energy- to laser rays. This energy is 
not stable, but is continually evolving and changing. It transforms and goes from one form to another. For example, it is suggested that matter breaks down into energy and this into something even more subtle -information- as proposed by Prigogine. The process is also inverted but is not reversible. For it to change direction a mutation has to be produced. The quantity of information will be that assigned by the direction of the energy evolution process of the Universe. For the time being, we have to think that we are still in the process that goes from.

matter $\rightarrow$ energy $\rightarrow$ information,

although this last is now so abundant that many philosophers and scholars, such as Jean Voge, the inventor of Infodynamics, are thinking in terms of a proximate mutation of the Universe (mentioned in -23-). There have even been forecast of "the end of the world" if the mutation cannot be realized. This would come about if a situation of an incapacity to perform a mutation is reached, for it is clear that in each process of change of

matter $\rightarrow$ to information

and of

information $\rightarrow$ to matte,

there is a decrease in matter and an increase in information. When everything is information, there will be no possibility of a mutation and the Universe will end. But when...?

\section{Humanity on the planet Earth}

Coming down to the planet Earth and the Humanity that inhabits it, we can apply our previous reasonings. Humanity behaves like a closed system, as it does not have other Humanities with which to relate. We, of course, understand that we referring to it in a social dimension because, in general terms, it is subject to all types of influence which, at present, we are incapable of identifying or quantifying.

Because it is a closed system and now has a considerable level of information, it will either have to transmute or die. Humanity has chosen the optimistic solution, that of transmuting. We have only to look around us to realize that this is what is happening.

Once again information plays the role of the vital element for the development of Humanity and the Universe.

\section{An idea of culture}

Moving on now to the second part of my talk. Which deals with the influence of information on the culture of peoples, I feel it is necessary to define what I mean by culture.

We are in an age of tremendous confusion. Everything evolves so quickly that there is scarcely time to assimilate each innovation. People are also suddenly faced with new concepts and new words, without understanding their meaning, nor do they understand the different and changing senses of concepts, within this age of transmutation. 
Among this concepts in that of culture which here we will take to be the set of acquired learnings, and we pluralize its content so as to include the different disciplines of the total "human knowledge", from humanities, history... to applied sciences, chemistry, computing... In other words, within the concept of culture are united theoretical ideas and practical applications, manifestations of reason and of spirit. This leads us to consider that there can exist a humanistic culture as well as a technological culture. Taking this into account, civilization will be the degree of culture of each people, at each given historical moment, within a process of elaboration of information.

Throughout history we can distinguish periods that are characterized by certain civilizations: the nomadic and hunting, agricultural, cattle raising. Bronze and iron civilizations and so on to the oil civilization. In each and through the influence of information, intelligence increasingly predominates over the use of muscular strength. This has reached such a point that many writers, among

If these theories are confirmed, we could think that the cycle is closing, beginning with the origin of Humanity as a homogeneous whole and ending by returning to that equality. Will this mean the end of the human race? In any respect, qe are far from achieving that homogeneity.

Let us now return to the culture of peoples.

\section{Evolution of the technological culture}

Certain people developed their intelligence and achieved a more comfortable and easier life. With regard to their technological cultural evolution, they began by attempting to substitute brute muscular force by certain tools: knives, axes, needles, the wheel, the pulley, and the plough. The first industrial revolution occurred over long periods of time. So long that the word "revolution" is inappropriate.

Discoveries and inventions took place, but always from the basis of muscular strength, assisted and replaced by tools. Tools that man knew and used with confidence, though the job he carried out was nevertheless laborious.

With time, new tools appeared. These tools were more complicated, resulting from the discovery of the steam engine, and later electricity and enabled man to substitute muscular energy by mechanical energy. There was a second industrial revolution in a much shorter period of time. Information had a positive effect, not only because of the greater amount produced in the long years before, but also because of the increased amount resulting from the technological advance in itself. This influenced working conditions, which changed considerably, and consequently living conditions improved.

Not a great deal of time has elapsed since then. There has been in practice, through a continuous process, a third industrial revolution, which is characterized by the use of "new technologies", based on semiconductors, computers, laser rays, servomechanism. Mechanical force has begun to be substituted by intelligence force. For the same reason the we mentioned before, information has begun to increase, and this time almost alarmingly, to the point that, in order to assimilate and transmit this information, Humanity has found itself forced to initiate a transmutation in its associated life.

Work is becoming easier. What before was considered God's punishment, is now becoming a desired and scarce commodity. Information has brought about these changes in technological culture. The greater the information, the faster the change. I feel it convenient to explain that in these cases I am referring to information as the sum 
of a series of products and phenomena resulting from mental activities that can be grasped and assimilated in order to realize a new technical development.

\section{Evolution of the humanistic culture}

Let us now look back on what has happened with respect to humanistic culture, reflected in a communication between peoples, in an alternating flow. It is manifested by the word, spoken, and later written, and now computers that work directly with the spoken word, thereby eliminating the intermediate step of writing.

Our mind is constructed in such a way that it is easier for us to understand how Humanity has evolved through language, because this is our means of communication with the external.

The primitive oral tradition was slow. Information was transmitted from generation to generation, over longs periods of time and in small geographical areas. The oldest person was the one who knew most and consequently was the most respected.

When writing was invented the evolutionary process accelerated, although it still belonged to a privileged few, who preserved the cultural traditions. The elders were still venerated and admired for their knowledge, because the oral tradition was still in force. As a person of letters would have expressed it, these were "stories at the fireside".

It is very interesting to see, from reading Hipólito Escolar $(12,13)$, how those periods in which the book industry has flourished, in some way or another, have coincided with stages of rapid evolution of Humanity. In times of war, catastrophes, plagues and other calamities; times in which books took refuge in convents and palaces, and were not easily accessible, this evolution was almost paralysed. Because of the scarcity of information... the brain develops more slowly and there are fewer inventions and discoveries.

It was paradoxical that, until the printing press economic and political power. It is therefore generally considered that information cannot be allowed to circulate and limited.

What solution is there to this dramatic panorama? We have to hope that information itself will make us realize how mistaken we are in our lives. Information is unique in that it can lead us to the human being's maximum aim, to knowledge through truth. By its intervention, our power to discriminate will increase and we shall come to understand the path we should follow to achieve a well-being and harmony between peoples, with whom we are unavoidably obliged to live on this Earth.

There is constant talk at present of the end of the world. There are even people who mathematically demonstrate that this end will take place at the beginning of the $21^{\text {st }}$ Century. It will neither be the end of this planet nor of the life on it. It is however possible that certain catastrophes will occur and that these could considerably diminish Humanity.

My own personal opinion is that the end of the world -of Humanity- will come about when we have achieved that knowledge we strive for, though information. 


\section{References}

(1) J. Aracil, Introducción a la Dinámica de Sistemas, Alianza Universidad, Textos (Alianza Editorial, Madrid, 1983).

(2) H. Arntz, Information and the Emergente of Man. "Boundaries in Evolution. Primary Study for a Paleology of Information", FID 627. Federation Internationale de Documentación, The Hague, 1983.

(3) F.J. Ayala, El Evolucionismo no está reñido con la religión, ABC, Sábado Cultural, 25 enero 1986.

(4) J.M. Berenguer Pena, Empresas de la tercera ola, Fundesco 43 (1985) 4.

(5) E. de Bono, Curso metodológico para aprender a pensar, Universidad de Cambridge, Trbajo mecanografiado, 1979.

(6) D. Campillo, en: Historia Universal, Vol. I (Salvat Editores, Barcelona, 1980).

(7) E. Currás, Las Ciencias de la Documentación. Bibliotecología. Archivología. Documentación. Información (Mitre, Barcelona, 1982).

(8) E. Currás, ¿Estaremos en la época del Informacionismo?, Revista de la Universidad Complutense 2, (1981).

(9) E. Currás, Moral and Social Implications of the New Technologies in Information Science, in: A. Van der Laan and A.A. Winters, eds. "The Use of Information in a Changing World”, FID Publications 631 (North-Hollan, Amsterdam, 1984).

(10) E. Currás, Some scientific and philosophical principles of information science. Nachr. for Dokum, 36 (3) (1985).

(11) J.C. Eccles, Ciencia y Cientifismo, ABC -Tribuna Abierta. 28 mayo 1985.

(12) H. Escolar, Historia de las Bibliotecas, Madrid, Biblioteca de Bolsillo, Fundación Sánchez Ruipérez, 1985.

(13) H. Escolar, Historia del Libro, Madrid, Biblioteca de Bolsillo, Fundación Sánchez Ruipérez, 1984.

(14) E. Gutiérrez Ríos, La Ciencia en la vida del hombre. Pamplona, Eunsa, 1975.

(15) P.N. Kaula, Perspectiva of Information systems and services in India. INICAE, September 1984, pp. 124-138. 
(16) A. King, La situación de nuestro planeta. Informes al Club de Roma. Madrid, Taurus Ediciones, 1978 (versión española de Gregorio Cantera).

(17) J.R. Lacadena, Francisco José Ayala: El Evolucionismo no está reñido con la religión. ABC, Sábado Cultural 25, Enero 1986.

(18) P. Lain Entralgo, Discurso en Congreso de las Academias de la Lengua, La voz del Libro 13 (Diciembre 1985).

(19) A.R. Luria, Lenguaje y Pensamiento, Breviarios de la Conducta Humana. Nr 16 (Editoral Fontanella, Barcelona, 1980).

(20) F. Mayor-Zaragoza, Configurar el futuro, ABC, Ciencia y Futuro, 28 mayo 1985).

(21) F. Mayor-Zaragoza, Investigación Científica y Metas Sociales. Hacia un Nuevo Modelo de Desarrollo (Editorial Alambra, Madrid, 1982).

(22) A. Morcillo Corvetto, Evolución y Megantropía, el modelo matemático de la evolución en base a la Teoría de Sistemas, "Seminario sobre Teoría de Sistemas Generales", Universidad Politécnica de Madrid, Trabajo mecanografiado, Madrid, 1980.

(23) A. Morcillo Corvetto, La nueva perspectiva de la infodinámica, La transición del paradigma, "I Seminario Hispano Luso Sobre Sistemas generales a información tecnológica”, Trabajo mecanografiado, Madrid, 1980.

(24) B. Morse, The full meaning of communication, Inter. Inform. Comm. and Educ. (INICAE) 3 (2) (1984).

(25) S. Ochoa, Ciencia e Investigación, ABC Editorial, 25 enero 1986.

(26) A. Peccei, Antes de que sea Demasiado Tarde (Taurus, Madrid, 1985).

(27) J.L. Phillips, Los Orígenes del Intelecto Según Piaget, Conducta Humana 4 (Editorial Fontanella, Barcelona 1977).

(28) J.M Rodríguez Delgado, Desarrollo de un sistema referencial mental, Ponencia presentada a SISBER 82, Trabajo mecanografiado, Madrid, 1982.

(29) F.J. da Silveira Saragoça, Consideraçoes generalis sobre a problemática de informaçao. Rev. Esp. Doc. Cient. 3 (2) 81980) 159-168.

(30) H. Simon, Conferencia Inaugural de la Jornada sobre Inteligencia Artificial; en: "Simposio Internacional Sobre Ingeniería del Conocimiento", Universidad Politécnica de Madrid, Madrid, 1985.

(31) V.I.Vernadsky, Reflexiones de un naturalista, en: "Ideas Científicas Como un Fenómeno Planetario", Tomo 2, 1977. 
(32) V.I. Vernadsky, Selected Words in the History of Science (Nauta, Moscow, 1981).

(33) E. White, El primer Hombre (Time-Life-International, New York, 1976).

(34) G. Barraclough, ed., El Mundo. Gran Atlas de Historia. Tomo I (Ebrisa, Barcelona, 1985) 